\title{
Age Matters: The Contingency of Economic Distance and Economic Freedom in Emerging Market Firm's Cross-Border M\&A Performance
}

\author{
Ru-Shiun Liou ${ }^{1} \cdot$ Rekha Rao-Nicholson ${ }^{2}$
}

Received: 9 January 2018 / Revised: 17 November 2018 / Accepted: 6 February 2019 /

Published online: 16 April 2019

(c) The Author(s) 2019

\begin{abstract}
The primary studies on emerging market multinational firms (EMFs) thus far have depicted a picture of accelerated internationalization in which EMFs conduct a series of aggressive cross-border acquisitions to further enhance their competitive advantage. However, it is not clear whether the EMFs which conducted the acquisitions at a young age experience better performance. EMFs constrained by their home market development in economic institutions may encounter different challenges in their cross-border acquisitions. Using a sample of South African firms' acquisitions between 1994 and 2012, we find support for the benefit of foreign acquisitions at a young age as well as the moderation effects of economic distance and economic freedom. While early inorganic growth provides an excellent opportunity to propel South African firms' growth, the country level factors present important boundary conditions to examine the benefit of early internationalization. While facing a significant economic distance, older firms are better at utilizing their experience and experience better post-acquisition operating performance. By contrast, the younger firms benefit more from the post-acquisition when the home country has weaker economic freedom.
\end{abstract}

Keywords Emerging-market multinational firms $\cdot$ South African firms $\cdot$ Economic distance $\cdot$ Economic freedom $\cdot$ Cross-border post-acquisition operating performance

Authorship is equally shared by both authors and the authors are listed in the alphabetic order.

Ru-Shiun Liou

rliou@ut.edu

1 John H. Sykes College of Business, The University of Tampa, Tampa, FL, USA

2 Newcastle University London, London, UK 


\section{Introduction}

Lacking market-supporting institutions back home, emerging market multinational firms (EMFs) often choose to acquire internationally at an early stage of the company's development to escape the institutional constraints in their home markets. Particularly, based on case studies of Asian EMFs, Mathews (2006, 2017) suggest that lacking ownership advantages, EMFs follow a trajectory of Linkage-Leverage-Learning (LLL) and turn the latecomer disadvantage into an advantage, when EMFs successfully leverage the strategic assets of the connection with the target firms as well as replicate the learning organizational capabilities to expedient its trajectory for global expansion.

While pioneering studies shed light on how some successful EMFs leverage their acquisitions of established targets to gain competitive advantages, we do not have a clear understanding about under what circumstance EMFs' early inorganic growth via acquisitions benefits their overall firm performance, and specifically whether the young EMFs enjoy better post-acquisition performance than the older EMFs. The age of the internationalizing firm has been shown to play a key role in the outward investment activities (Aykut and Goldstein 2007; Jones 1999). Older firms with established organizational capabilities (Barney 1991; Peteraf and Barney 2003; Schreyögg and Kliesch-Eberl 2007) have internal resources, industry knowhow, capital access and longer domestic presence which might help them in generating organic and inorganic growth in the foreign markets, whereas, the younger firms often have strategic agility (Criscuolo and Narula 2007) and less domestic ties which might impel them to access international markets for resources and capital (Cuervo-Cazurra 2012; Makino et al. 2002; Ramamurti 2016). Thus, it remains an intriguing issue as for whether young and old EMFs perform differently, particularly after conducting cross-border acquisitions.

Empirically, a few studies focus on the short-term stock performance after EMFs announce their cross-border acquisitions (e.g., Aybar and Ficici 2009; Nicholson and Salaber 2013). Findings of this line of research support that crossborder acquisition announcements lead to value enhancement in EMF acquirers' stocks when those acquisitions are made in developed markets (Aybar and Ficici 2009; Nicholson and Salaber 2013). In other words, the announcement effect exists such that stockholders recognize the benefits for EMFs in acquiring valuable targets in the developed markets. However, according to the M\&A literature, acquirers assess the potential synergy before the acquisition, but the post-acquisition integration usually present challenges that are not well anticipated before the acquisitions (Björkman et al. 2007).

Considering the post-acquisition integration, we propose that the effect of firm age on EMFs' post-acquisition operating performance calls for an understanding of the contextual factors in host and home institutional environments South Africa provides a unique setting as it has experienced colonization as well as apartheid, and, over last 25 years, has integrated into global economy. South Africa (SA) has experienced rapid growth in its GDP from 136 trillion US dollars (2000) to close to 350 trillion US dollars (2014) (UNCTAD 2015). To delineate the intricacy of 
the post-acquisition operating performance, we integrate the literature of institution-based view and LLL framework to delineate the significant opportunities afforded in the cross-border acquisitions for SA firms in the historical context of South Africa between 1994 and 2012. First, we review relevant institution-based view literature on EMFs' post-acquisition performance and discuss the historical context of colonization and apartheid in South Africa. In the context of our study, LLL framework is ideal as it helps identify the benefits of linkages via cross-border acquisition with the foreign company and leverage target's strengths as well as learn about foreign markets (Mathews 2002, 2006). Second, we offer hypotheses to study the age effect of South African firms on their post-acquisition performance in light of the economic distance and home country economic freedom. Economic distance, defined as the difference in the economic development of the host country relative to that of the home country, reflects the differences in factor costs and technological capabilities between the host and home countries (Ghemawat 2001; Tsang and Yip 2007). Economic distance does not only signify the learning opportunities but also presents the challenges for post-acquisition integration that requires considerable resources and efficient reconfiguration of organizational resources. In addition, the lack of economic freedom explains some SA acquirers' motivation to acquire a target in a foreign country to diversify the heightened risks in their home markets. Third, we report the methodology and results as well as offer a discussion on the implications of our findings.

Overall, we take an integrative approach and build on the LLL framework to examine SA firms' post-acquisition operating performance. We contribute to the researchers' recent call for more understanding of the interaction between the firm level and country level characteristics for SA firms' internationalization (Lu et al. 2017; Meyer et al. 2009; Ramamurti 2016). Lu et al. (2017) reviewed the studies on dragon multinationals and suggested that original LLL framework developed by Mathews (2006) downplayed the critical factors of the EMFs' home institutional environment. As mentioned in the recent review article of springboard EMFs (Luo and Tung 2018), the inorganic growth via cross-border acquisitions provides an excellent opportunity to propel SA firms' growth by augmenting their strategic capabilities and reducing their vulnerability to home institutions. Current study bridge both Springboard perspective and LLL framework (Mathews 2006, 2017) and propose that the country level factors present important boundary conditions to examine the LLL benefit of internationalization for EMFs. Using a sample of SA firms' acquisitions between 1994 and 2012 and post-acquisition performance over threeyear period, we find support for the benefit of foreign acquisitions at a young age as well as the moderation effects of economic distance and economic freedom.

\section{Literature Review}

\subsection{Institution-based View of EMFs' Internationalization}

In recent years, foreign direct investment originated from emerging economies accounted for a quarter of the worldwide foreign direct investment (UNCTAD 
2015). These emerging-market multinational firms (EMFs) are shown to have used their foreign investments to exploit the host-home institutional environmental differences (Cuervo-Cazurra 2012; Makino et al. 2002; Ramamurti 2016). The rationale for the EMFs' inorganic growth, via acquisitions, in foreign markets with regards to the host-home institutional environments is twofold. First, EMFs gain competitive advantages when they acquire established firms' advanced technology and managerial know-how as well as the reputable brand and distribution channel (Elango and Pattnaik 2007; Li et al. 2012; Luo and Tung 2007). Such valuable targets are less likely to be available in EMFs' home economies (Cuervo-Cazurra 2012; Makino et al. 2002; Mathews 2006). Second, in addition to the traditionally conceptualized 'pull' factors for foreign expansion, such as gaining additional market share in a larger foreign market, 'push' factors including weak institutions and economic underdevelopment in their home countries drive EMFs to acquire in foreign countries (Cuervo-Cazurra and Ramamurti 2015). As shown in the collection of studies on EMFs, EMFs seek accelerated internationalization to acquire much needed strategic assets, such as advanced technology and managerial know-how (Elango and Pattnaik 2007; Li et al. 2012; Luo and Tung 2007) as well as to escape the institutional constraints in their home markets with weak market-supporting institutions (Cuervo-Cazurra and Ramamurti 2015; Makino et al. 2002; Ramamurti 2012).

Some EMFs demonstrate the characteristics of the advanced-market firms' internationalization activities, like targeting underdeveloped countries' resources for strategic complementary or market development in underrepresented markets. For example, the Chinese EMFs' rapid expansion in Africa is mainly driven by their strategic resource seeking in these countries (Kolstad and Wiig 2011). Other EMFs have utilized internationalization to escape from the limited domestic market condition. For instance, SabMiller, a brewing and beverage company founded in South Africa, has chosen to operate globally to avoid governmental control over foreign exchange usage (Luo and Tung 2007). In essence, bounded by unique institutional conditions in their home markets, such as lacking stable market-supporting institutions and well-developed economies, EMFs often demonstrate an urgent need for accelerated internationalization (Guillén and Garcia-Canal 2009; Mathews 2006) and conduct a series of aggressive cross-border mergers and acquisitions to expediently expand their international business (Aybar and Ficici 2009; Li et al. 2016).

\subsection{Linkage-Leverage-Learning (LLL) Framework}

A few researchers have suggested that EMFs possess a unique market-based advantage, which refers to the advantage developed based on the country-specific resources to compete against other firms in the industry (Cuervo-Cazurra and Genc 2011). EMFs have advantages in providing lower cost products as well as in designing products for a niche market, particularly serving emerging market customers. EMFs' cost advantage is mainly derived from the factor endowment in their home country, such as cheaper labour and raw materials (Sun et al. 2012). Since the 1950s, lower trading barriers have encouraged foreign direct investment, and established multinationals have shifted their manufacturing facilities to less developed countries 
to capitalize on relatively lower wages. Low labour cost becomes the major location-specific advantage among these less developed economies (Porter 1990). Such a location-specific advantage, however, is readily utilized by other firms which have operations in these countries and does not constitute an EMF's unique competitive advantage over their developed-market counterparts (DMFs). Built upon the location-specific advantage of low production cost, EMFs primarily propel their growth through innovation which focuses on the unique needs of the emerging economies (Mathews 2006).

Several researchers suggest that successful EMFs build their competitive advantage by utilizing their connections and linkages with DMFs (Guillen and Garcia-Canal 2009; Mathews 2006; Wright et al. 2005). In combining the cost advantage and local knowledge of serving emerging market customers, EMFs can build their competitive advantage by utilizing existing technology or business models previously developed by DMFs to design innovative, affordable products to better serve emerging market customers. Mathews (2006) Linkage-Leverage-Learning (LLL) framework further elaborated EMFs' competitive advantage of leveraging connections and revised Dunning's (1980) Ownership-Location-Internalization (OLI) framework. By establishing linkages (L) with DMFs through partnerships or acquisitions, successful Asia Pacific firms developed their competitive competences by leveraging (L) the connections associated with DMFs. Through the leveraging experience, these dragon multinationals learned (L) how to compete with DMFs by replicating the success of linkage and leverage. For instance, originating from Taiwan as a PC assembler, Acer accelerated its internationalization through a series of acquisitions and partnerships with established firms in various target markets and became one of the most successful PC components, PC, and IT firms in the world (Mathews 2006).

\subsection{South African Institutional Environment and South African Firms' Foreign Acquisitions}

In the current study, we take a closer look at the South African firms which were born before and after 1994 when Apartheid ends, hence, it is important to contextualize the firm strategy within this institutional context. South Africa has experienced both Dutch as well as the British colonization over several centuries beginning in 1600s. The Dutch East India company formed its resupply station in Cape Town in 1650s to support the activities of the fleet arriving from its home country and its colonies from other part of the world. Early part of the colonization was driven by the local communities' reluctance to collaborate with the Dutch settlers in supporting their trade plans with South Africa. For example, when Khoisan people, natives of Cape Town, refused to supply provisions to the arriving Dutch fleets, Europeans used firearms and military actions to gain control of the coastal regions which drove natives to the interiors of Africa.

In the next stage of colonization, the farming activities were localized with the white European settlers and slaves were brought from rest of the Africa and Asia to work on these lands. On one hand, this concentrated power and rights with the minority of the population, and on the other hand, inclusion of people from other parts of the world 
increased the local diversity in the population. The power continued to be centered mostly in white population and over the decades, South Africa saw arrival of French Huguenot refugees and Germans. The Dutch and Germans continued to settle in the Cape founding the Afrikaner segment. Following shift in the powers in the Europe, where France occupied the Netherlands, the Great Britain occupied the African territories to secure access for their trading fleet to Asia and other parts of the world through Africa. Following the ensuing battle between various European powers, British set up a colony in South Africa.

Clashes emerged between the Boers (Afrikaner farmers) and British as the Great Britain outlawed slavery and started the rehabilitation and advocating of freedom for slaves. These battles lead to dominance of Boers over the British rulers, and they established two independent republics-Transvaal and Orange Free State. In 1910, the Union of South Africa was formed (Davenport and Saunders 2000), which later claimed independence and concluded British colonization by diplomatic measures.

This long-term colonization had long-lasting effects in several ways. The legal system in the UK and South Africa are similar in nature, and we observe the same thing for the financial system (Weimer and Vines 2011). Within South Africa itself, the apartheid rule lead to generations of South Africans who had limited access to education and equal opportunity to employment. Most of the jobs in the top levels of the organization were restricted to white South Africans. During the apartheid rule, many foreign investors stopped investing in South Africa and this led to years of isolation for the South African business and trade.

Once the South African apartheid rule was abolished and first black South African president, Nelson Mandela, was elected in 1994, South Africa was quickly welcomed back into the global trade and development activities. In recent times, South African firms initiated almost two out of five acquisitions in Africa (Ernst and Young 2012). Liou and Rao-Nicholson (2017) note that colonial tie has a negative impact on the cross-border activities of the South African firms in the developed countries, and at the same time, this colonial tie reduces the impact of the institutional distance between the host and home countries. The presence of colonial history between the countries can create biases in the employees of the acquirers and targets, for example, the developed country target's employees might consider themselves superior to the acquirer's employees and might be unwilling to work with the ex-colony's employees. Similarly, the acquirer's employees might reflect on their country's colonial past and observe developed country target's employees with distrust and be unwilling/unable to assert their power and status in their negotiations with target's employees. These issues can make the working relationships quite fragile and post-acquisition integrations highly laborious and risky.

\section{Hypotheses Development}

\subsection{Firm Age and South African Firms' Post-acquisition Performance}

Organizational capability, defined as a firm's established routine that has a successful track record in allocating resources, has long been theorized to differentiate one 
firm's competitive advantage from another firm's (Barney 1991; Peteraf and Barney 2003; Schreyögg and Kliesch-Eberl 2007). Some may argue that older SA firms possess a different set of organizational capabilities. EMFs' research suggests that despite lacking the technological and managerial capabilities possessed by established multinationals in the advanced economies, EMFs have non-market advantages which refer to the advantages based on the EMFs' operation in their home country's specific institutional environments (Cuervo-Cazurra and Genc 2011). Emerging economies are characterized as low in environmental munificence and high in environmental uncertainty because of a less developed economy as well as lacking market-supporting institutions (Alon et al. 2013; Peng et al. 2008). Established EMFs are believed to be more equipped to navigate the uncertainty associated with a weak institutional environment, such as the apartheid in South Africa (Cuervo-Cazurra and Genc 2011; Ramamurti 2016).

By contrast, young EMFs do not have the legacy issue as do old EMFs. Internally, the inertia in older EMFs might further taint their strategic decision making (Criscuolo and Narula 2007). Externally, older EMFs with reputation of operating under the older regime in their home country might experience resistance from host country stakeholders during post-acquisition integration (Ellis et al. 2015). Especially in the recent years, many emerging economies experience rapid economic growth and the home markets of EMFs are able to provide a more munificent business environment (Estrin et al. 2018). Likewise, the young South African firms are born in an era after Apartheid and the institutional environment is more conducive for a well-connected global economy, in which young South African firms are more likely to have a global orientation to capitalize their cross-border mergers and acquisition and improve the overall firm performance due to the linkage, leverage and learning (LLL) benefits (Matthew 2006).

Hypothesis 1: Ceteris paribus, younger SA firms experience better post-acquisition operating performance than older SA firms' in their foreign acquisitions.

\subsection{Economic Distance and EMFs' Post-acquisition Integration}

An institution-based view on emerging economy suggests that institutional environment differences can be regarded as sources of innovation and creativity that are beneficial in a rapidly changing environment (Reus and Lamont 2009; Stahl and Tung 2015) as well as sources of liability of foreignness that hinders a foreign acquirer's ability to understand the formal and informal rules in the host market (Eden and Miller 2004; Kostova and Zaheer 1999; Xu et al. 2004). Economic distance denotes the economic status difference between the host and home markets and presents a double-edged sword for EMFs' cross-border mergers and acquisitions. On the one hand, EMFs can benefit from resource exploitation by expanding into the countries with less economic development, while seeking the opportunity of resource exploration in the countries with more economic development (Makino et al. 2002; Tsang and Yip 2007). On the other hand, the economic distance can potentially bias a foreign firm's understanding of the consumers' purchasing preferences, hence 
decreasing the foreign firm's success in the host market (Ghemawat 2001). Also, in the eyes of host market stakeholders, EMFs originated from less developed economies historically bear the country-of-origin stereotypes of providing inferior goods that are made by cheaper labor, thus adding to the liability of foreignness (Kostova and Zaheer 1999; Liou et al. 2017).

Initial studies on EMFs' short-term stock performance suggest that EMFs' acquisitions on average lose value in the developing countries, whereas acquisitions in the developed countries generate a greater value for EMFs (Aybar and Ficici 2009; Nicholson and Salaber 2013). Nevertheless, for the post-acquisition operating performance, we argue that the assimilation process poses a major hindrance for EMFs to fully accrue the benefits of synergy expected in the economic distance during the post-acquisition integration period. EMFs do not only have to assimilate activities across two different national contexts, but also have to reconcile the competing legitimacy requirements in the host and home institutional environment (Ataullah et al. 2014; Li et al. 2016; Liou et al. 2017). The differences in economic development status between the host and home markets are likely to present the challenges in managing the integration among different innovation systems, capital markets, and supply chains (Cuervo-Cazurra 2012).

Due to the newly emerging status, SA acquirers may lack the international experience and managerial expertise to navigate the intricacy of the host-home country differences in economic development. Given the challenges associated with the drastically different economic environment, research suggests that older firms are in a better position to utilize competitive advantages, such as existing client base, reputation and social capital, to enhance the organizational performance (Anand and Delios 2002; Hamel and Prahalad 1993; Ismail et al. 2010; Stinchcombe 1965). By contrast, young EMFs that internationalize into a foreign market face two challenging tasks including building legitimacy at home as well as in the host markets (Sapienza et al. 2006). As an EMF grows older, it builds organizational capability which can better absorb the shock of drastically different legitimacy requirements in the host-home institutional environments. A recent study on Chinese listed firms also suggests that older companies with more experience have the greater absorptive capacity, which results in a better position to overcome the cultural differences and enjoy better stock return after the acquisitions events ( $\mathrm{Li}$ et al. 2016). Likewise, Lu et al. (2017) reviewed recent studies based on dragon multinationals and expanded LLL model to an extended framework of inward linkages-outward linkages-leverage-learning (IOL3) framework. Lu et al. (2017) observed that beyond the outward linkages, established dragon multinationals also developed inward linkages within their home market, so they can garner home country resources which are instrumental in propelling EMFs' further internationalization. Hence, we propose that older EMFs are better equipped with the needed experience and capabilities to navigate the complexity of formal and informal institutions in the host market and enjoy the LLL benefits afforded in the economic distance. Thus, entering an economically distant country, older SA firms which possess established organizational capabilities will be more capable of attaining the LLL benefits afforded in the drastically different economic environment and enjoy a better post-acquisition operating performance. 
Hypothesis 2: Ceteris paribus, facing larger economic distance, older SA firms experience better post-acquisition operating performance than younger SA firms.

\subsection{Home Market Economic Freedom}

To further probe the country level contingencies of the firm age effect on EMFs' post-acquisition performance, we study one common institutional characteristic shared among emerging economies-lack of economic freedom in the home country. According to the Heritage Foundation, economic freedom refers to the absence of government coercion or constraint on the production, distribution or consumption of goods and services (O'Driscoll et al. 2003). Emerging markets are commonly characterized by 'weak' formal market-supporting institutions, such as their legal framework and enforcement, property rights, information systems, and regulatory regimes (Meyer et al. 2009). Whereas market-supporting institutions are strong in developed markets, weak market-supporting institutions in emerging markets may "fail to ensure effective markets or even undermine markets (as in the case of corrupt business practices)" (Meyer et al. 2009, p. 63). The SA has experienced great degree of change in its economic fortune, and in recent times, has developed business friendly policies to attract both domestic and foreign investment. The SA's trade freedom values have risen from 43 in 1995 to 76.1 in 2014 (Heritage Foundation 2014).

As the emerging markets become more competitive in the world economy, recent research suggests that these emerging markets will experience a transition process from a "relationship-based, personalized transaction structure to a rule-based, impersonal exchange structure" (Peng 2003, p. 275). The level of development in the market-supporting institutions in EMFs' home country has great implications on EMFs' LLL capabilities (Tian 2017). During the transition process, young SA firms which operate in an uncertain environment can potentially utilize the opportunity of acquiring foreign targets as an leverage to escape the relatively uncertain market conditions in their home markets. Along this line of reasoning, the younger SA firms which escape underdeveloped home country institutional systems and acquire valuable targets in the foreign market will enjoy the benefit of internationalization, especially, if the home country environment limits their economic freedom of conducting business. By contrast, older SA firms have established ownership advantages, such as a market-leading position and production efficiency and are in a better position to absorb the deficiency in the economic freedom in their home market. Hence, we propose that young SA firms, in contrast with older SA firms, will benefit more from cross-border acquisitions when their home market has a lower level of economic freedom.

Hypothesis 3: Ceteris paribus, facing lower home country economic freedom, younger SA firms experience better post-acquisition operating performance than older $S A$ firms. 


\section{Method}

\subsection{Sample}

The data on cross-border acquisitions come from Thomson One database provided by SDC Platinum of Thomson Financial Securities Data Worldwide Mergers and Acquisitions Database. The Thomson One database has been extensively used in studies which involve cross-border acquisitions (Liou et al. 2017; Liou and RaoNicholson 2017; Nicholson and Salaber 2013; Tan and Chintakananda 2016). It contains all information on the deals conducted in the world. The data provided by Thomson One includes the transaction value, the percentage of shares acquired, and shares owned after the transaction, country and industry of each bidder and target, and the mode of payment. We downloaded the data from the website using the following criteria: (1) the acquisition was completed; (2) the bidder owned a majority stake in the target company after the transaction; (3) the home country of the bidder is South Africa; and (4) deal was public. We observe that in some cases, these values are missing in the Thomson One database, and one of the reasons for this is that it is not mandatory to disclose the deal details in the public domain. At this stage, we have 100 deals conducted from 1994 until 2012. ${ }^{1}$

We considered post-merger performance three years after the acquisition. Hence, to be included in the sample, bidding and target firms need to have the accounting data available for at least three years before and after the takeover. OSIRIS and FAME database are used to collect the accounting data up to three years prior and after each transaction. Hence, we collected the performance data for the years between 1991 and 2015. This procedure is consistent with empirical research in this area as the post-acquisition operating performance induced from corporate takeovers are usually not materialized in the same year of acquisition (Healy et al. 1992). Many of the acquirers and targets did not have 3 years of performance data, and hence, these deals were not included in the final sample. We compared the deal values of the deals not included in our sample to those that were included in our sample, we do not observe any major issues with our missing data.

Table 1 presents descriptive statistics of our final sample of 92 acquisitions conducted by the South African firms in both developed and developing economies. Panel A reports the number of acquisitions in the sample period. It is noticeable that the number of acquisitions increased drastically in the early 2000s, just before the publication of the BRICS report when South Africa along with other BRICS countries was suddenly catapulted into world stage (Wilson and Purushothaman 2003). In Panel B, we separate targets in developing and developed economies. Consistent with past studies, EMFs' cross-border acquisitions are mainly to acquire valuable targets in the developed countries. While 19 acquisitions took place in the developing economies, 73 acquisitions were undertaken in the developed economies.

\footnotetext{
1 We restrict deals in our sample to up until 2012 as we need three years of post-acquisition data to conduct our empirical analysis. As this data was collected in late 2016, we had accounting data until 2015.
} 
Table 1 Sample description

\begin{tabular}{|c|c|c|c|c|c|}
\hline \multicolumn{2}{|c|}{ Panel A: Completion year } & \multicolumn{4}{|l|}{ Panel B: Target nation } \\
\hline Year & No. of deals & Developed country & No. of deals & Developing country & No. of deals \\
\hline 1994 & 1 & Australia & 11 & Ghana & 4 \\
\hline 1996 & 2 & Austria & 1 & Ivory Coast & 1 \\
\hline 1997 & 3 & Canada & 6 & Kuwait & 1 \\
\hline 1998 & 5 & Finland & 1 & Lebanon & 1 \\
\hline 1999 & 4 & France & 1 & Mali & 1 \\
\hline 2000 & 9 & Germany & 1 & Namibia & 1 \\
\hline 2001 & 7 & The Isle of Man & 1 & Nigeria & 2 \\
\hline 2002 & 2 & Luxembourg & 1 & Rwanda & 2 \\
\hline 2003 & 3 & Netherlands & 3 & Slovenia & 1 \\
\hline 2004 & 4 & New Zealand & 1 & South Korea & 1 \\
\hline 2005 & 2 & Singapore & 1 & Swaziland & 1 \\
\hline 2006 & 11 & United Kingdom & 31 & Uganda & 2 \\
\hline 2007 & 8 & United States & 14 & Zimbabwe & 1 \\
\hline 2008 & 9 & & & & \\
\hline 2009 & 4 & & & & \\
\hline 2010 & 5 & & & & \\
\hline 2011 & 5 & & & & \\
\hline 2012 & 8 & & & & \\
\hline
\end{tabular}

\begin{tabular}{lllll}
\hline Panel C: Pre-1994 firms' target locations & & \multicolumn{2}{l}{ Panel D: Post-1994 firms' target locations } \\
\cline { 1 - 2 } Country & No. of deals & & Country & No. of deals \\
\hline Australia & 9 & Australia & 2 \\
Austria & 1 & Canada & 1 \\
Canada & 5 & Ghana & 1 \\
Finland & 1 & Ivory Coast & 1 \\
France & 1 & Lebanon & 1 \\
Germany & 1 & Netherlands & 1 \\
Ghana & 3 & Nigeria & 1 \\
Isle of Man & 1 & Rwanda & 2 \\
Kuwait & 1 & Singapore & 1 \\
Luxembourg & 1 & Uganda & 2 \\
Mali & 1 & United Kingdom & 8 \\
Namibia & 1 & United States & 6 \\
Netherlands & 2 & & \\
New Zealand & 1 & & \\
Nigeria & 1 & & \\
Slovenia & 1 & & \\
South Korea & 1 & & \\
Swaziland & 1 & & \\
United Kingdom & 23 & & \\
United States & 8 & & \\
Zimbabwe & 1 & & \\
Total & 65 & & & \\
\hline & & & \\
\hline
\end{tabular}




\subsection{Dependent Variables}

Several accounting-based post-acquisition performance measures have been used in the past literature (Haleblian and Finkelstein 1999; Hitt et al. 1998; Papadakis and Thanos 2010; Schoenberg 2006; Zollo and Meier 2008). It is beneficial to use the accounting-based measures to evaluate the post-acquisition performance because the potential synergies between the companies usually take several years to realize (Thanos and Papadakis 2012a). Hence, the synergy between acquiring and target firms is best observed by looking at the long-term accounting measures such as return on asset (ROA) and Profit Margin (Hitt et al. 1998; Papadakis and Thanos 2010; Thanos and Papadakis 2012b). Also, using several measures in a single study gives a more holistic view of the post-acquisition performance (Thanos and Papadakis 2012a). Following Bertrand and Betschinger (2012), Papadakis and Thanos (2010), and Zollo and Meier (2008), we calculate two measures of the post-acquisition performance, including ROA and Profit Margin (Thanos and Papadakis 2012a).

The pre-tax cash flow, an accounting-based performance measure, which is defined as sales, minus the cost of goods sold and selling, general, administrative expenses, plus depreciation is used in this study (Healy et al. 1992; Sudarsanam 2003). Rather than using the values of the raw operating cash flow, the usual approach is to deflate them before and after the deal, to make financial ratios comparable between companies and over time. The common bases used to scale the operating cash flows are the book values of assets and sales (Clark and Ofek 1994). Hence, we calculate two returns of the combined firm (i) for each year $(\mathrm{t})$ :

$$
\begin{aligned}
& \text { Profit Margin: Profit Margin } i, t=\frac{\text { Profit }_{i, t}}{\text { Revenue }_{i, t}} \text {, } \\
& \text { Return on Assets } \operatorname{ROA}_{\mathrm{i}, \mathrm{t}}=\frac{\mathrm{CF}_{\mathrm{i}, \mathrm{t}}}{\operatorname{ASSETS}_{\mathrm{i}, \mathrm{t}}} \text {, }
\end{aligned}
$$

where $\mathrm{CF}$ is the pretax cash flow. The accounting figures of target and bidding firms are aggregated in the years before the acquisition. Following Martynova et al. (2007), the pre-acquisition cash flow returns of the combined firm are calculated as the sum of cash flows of both firms scaled by the sum of their total assets or sales at the end of the year. Prior research has suggested that the data on the operation performance needs to be checked for any outliers which then are removed from the analysis for robustness of empirical analysis (Barber and Lyon 1997). We do not observe any exceptional items or outliers in our analysis. We calculate yearly Profit Margin and ROA using the method discussed above for the three years before and after the acquisitions of our sample firms. 


\subsection{Creation of Peer Sample}

To isolate the impact of the acquisition on the firm performance, we create a relevant benchmark for each transaction by matching the sample firms to the non-acquiring firms based on several criteria, including their industry, asset size and performance measures (Barber and Lyon 1997; Martynova et al. 2007). We use the OSIRIS and FAME database to identify a matched peer firm for each acquirer based on the industry, size and performance. In this process, the companies in the same sector as the EMFs are selected, and then the firms closest to the EMFs regarding their asset size in the year of acquisition are selected. This sample of non-acquiring firms is then further narrowed down to create the matched peer firm which is closest to the EMF regarding its long-term performance.

Following Barber and Lyon (1997) and Martynova et al. (2007), we decide to keep the same matched firm for each year of analysis which belonged to the same industry comparison group. Finally, this peer company's data is collected for our analysis:

$$
I A R O A_{\mathrm{i}}=R O A_{\mathrm{i}, \mathrm{t}}-R O A_{\text {ind_size_performance_peer, } \mathrm{t},}
$$

IAProfit Margin $_{\mathrm{i}}=$ Profit Margin $_{\mathrm{i}, \mathrm{t}}-$ Profit Margin $_{\text {ind_size_performance_peer, }, \mathrm{t}}$.

The results presented in this research are based on this benchmark to adjust EMF's performance compared to the matched peer firm that is created based on industry, size, and performance.

\subsection{Independent and Moderator Variables}

The Firm age is calculated by subtracting the founding year of the business from the year of the acquisition. The Firm age square is the squared term of company age. We use Berry et al. (2010) measure of the Economic distance and adopt a composite index of GDP per capita (2000 US\$), GDP deflator (\% GDP), exports of goods and services (\% GDP), and imports of goods and services (\% GDP). Then the Mahalanobis distance is used to calculate the distance between the two countries and is equal to the Euclidean distance calculated with the standardized values of the principal components [further details are provided in Berry et al. (2010)]. Home Market Economic Freedom Index is obtained from Economic Freedom Index data published by Heritage foundation. The Heritage Foundation has tracked and published an Index of Economic Freedom for 184 countries since 1995. A single index value of economic freedom has been widely utilized to capture the level of development of formal, regulatory institutions (e.g., Aybar and Ficici 2009). 


\subsection{Control Variables}

We include several control variables in this empirical analysis: the deal-level, firmlevel, and sector-level differences which control for deal, firm and industry-level effects. The choice of these variables is driven by the control variables used in extant literature. First, for deal-level characteristics, Same Industry $y_{i}$ is a dummy variable taking the value one when both bidder and target firms have the same first two SIC digits (Barber and Lyon 1997; Liou et al. 2018). This control variable is useful for controlling the effect of consolidation in our study (Denis et al. 2002; Moeller and

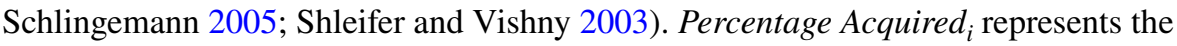
percentage of target share owned after the transaction. Researchers have argued that the acquisition performance is influenced by the ownership concentration (Moeller and Schlingemann 2005; Nicholson and Salaber 2013; Rao-Nicholson and Khan 2017). Cash $_{i}$ is a dummy variable equal to one when the deal is all cash financed, zero otherwise. This measure of Cash variable is similar to those used in other studies, among others, Beccalli and Frantz (2009), Beltratti and Paladino (2013), Chakrabarti et al. (2009), Díaz et al. (2009), Martin (1996), and Rossi and Volpin (2004). Studies have found that the cash acquisitions are associated with better postacquisition operating performance (Linn and Switzer 2001).

Second, for the firm-level characteristics, Business Group $_{i}$ is a dummy variable that represents if the acquirer is part of a business group and equal to one, zero otherwise (Rao-Nicholson and Cai 2018). Works of Popli and Sinha (2014) have highlighted the impact of business group on foreign investments. High Technology Target $_{i}$ is a dummy variable which is equal to one if the target belongs to the high technology industry, zero otherwise. Authors have argued that the high technology firms can leverage the acquired firms' existing knowledge as an input to their own innovation processes (Makri et al. 2010; Puranam and Srikanth 2007). Age (Target) is the age of the target at the time of the acquisition. Age of the target can indicate the experience and importance of this firm in the host country business environment. We also included Acquirer Profit Margin and Acquirer ROA as controls in our analysis. Extant studies have shown that size of the acquirer firms will have an effect on target performance (Moeller et al. 2004; Rao-Nicholson et al. 2016).

Third, for the country-level characteristics, the geographical distance indicator is included to control for geographical distance effects (Geographical Distance ${ }_{i}$ ) and Forex $_{i}$ to indicate the impact of the currency fluctuations (Berry et al. 2010; Ghemawat 2001). Hofstede Cultural Distance ${ }_{i}$ is the cultural distance calculated using the Hofstede's cultural determinants. GDP $(\text { Target })_{i}$ is the gross domestic product data for the target country, and it is obtained from World Bank. Economic Freedom Index Distance $_{i}$ is the difference between the economic freedom indices of the acquirer and target countries, and we collect this data from the Heritage Foundation (Berry et al. 2010; Ghemawat 2001). The Colonial Tie enhances the mutual understanding between the acquirer and target and is measured by a dummy variable which takes the value of one if the targets are based in the UK or the Netherlands and zero in all other cases (Liou and Rao-Nicholson 2017). 


\subsection{Analysis}

We perform a multivariate analysis to look at the effect of each variable on our adjusted performance measures. We regress the measures of post-acquisition performance on various deal characteristics and control variables, based on the following cross-sectional OLS model:

$$
\begin{aligned}
\text { ADJ_PERF }_{\mathrm{i}}(\text { post })= & \alpha_{0}+\alpha_{1} \text { ADJ_PERF }_{\mathrm{i}}(\mathrm{pre})+\alpha_{2} \text { EconomicDistance }_{\mathrm{i}} \\
& +\alpha_{3} \text { Firmage }_{\mathrm{i}}+\alpha_{4} \text { EconomicDistanceXFirmage }_{\mathrm{i}} \\
& +\alpha_{5} \text { EconomicdistanceXFirmagesquare }_{\mathrm{i}}+\alpha_{6} \text { Firmagesquare }_{\mathrm{i}} \\
& +\alpha_{7} \text { CONTROLS }+\varepsilon_{\mathrm{i}},
\end{aligned}
$$

$$
\begin{aligned}
\text { ADJ_PERF }_{\mathrm{i}}(\text { post })= & \alpha_{0}+\alpha_{1} \text { ADJ_PERF }_{\mathrm{i}}(\mathrm{pre}) \\
& +\alpha_{2} \text { Home Market Economic Freedom Index }_{\mathrm{i}}+\alpha_{3} \text { Firmage }_{\mathrm{i}} \\
& +\alpha_{4} \text { Home Market Economic Freedom Index XFirmage }_{\mathrm{i}} \\
& +\alpha_{7}{\text { CONTROLS }+\varepsilon_{\mathrm{i}}}
\end{aligned}
$$

where $A D J \_P E R F_{i}$ (post) is the post-acquisition adjusted performance of the com-

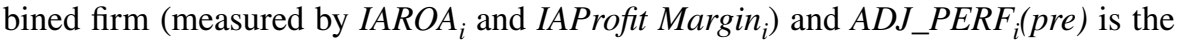
pre-acquisition adjusted performance of the combined firm. We also use the full model which has both variables of interest.

Table 2 reports the correlation coefficients and descriptive statistics across all our variables. We do not observe any significant correlations that could bias our analysis. Consistent with the extant literature, both pre-acquisition Profit Margin and ROA values are higher than the post-acquisition values (Bertrand and Betschinger 2012; Clark and Ofek 1994; Dickerson et al. 1997; Papadakis and Thanos 2010). We include country and year dummies in all of the empirical models.

\section{Results}

\subsection{Univariate Analysis for Pre- and Post-1994 Acquirers' Performance}

We examine the differences between the firms founded before and after 1994 using the univariate analysis. We observe from Table 3 that there are differences in the performance of the pre and post 1994 firms. For the post-1994 founded firms, the performance in developing markets is better than that in the developed markets [difference (Profit Margin) =-23.09]. For firms established before 1994, there is no performance difference between the developed and developing markets as the differences are not statistically significant. In the developed markets, firms established before 1994 do better than the firms founded after 1994 [difference (ROA) $=-6.99$, difference (Profit Margin) $=-9.24]$. In the developing markets, firms created after 1994 do better than the firms established before this year [difference (Profit Margin $)=11.82$ ]. Thus, firms established before 1994 should invest in developed 


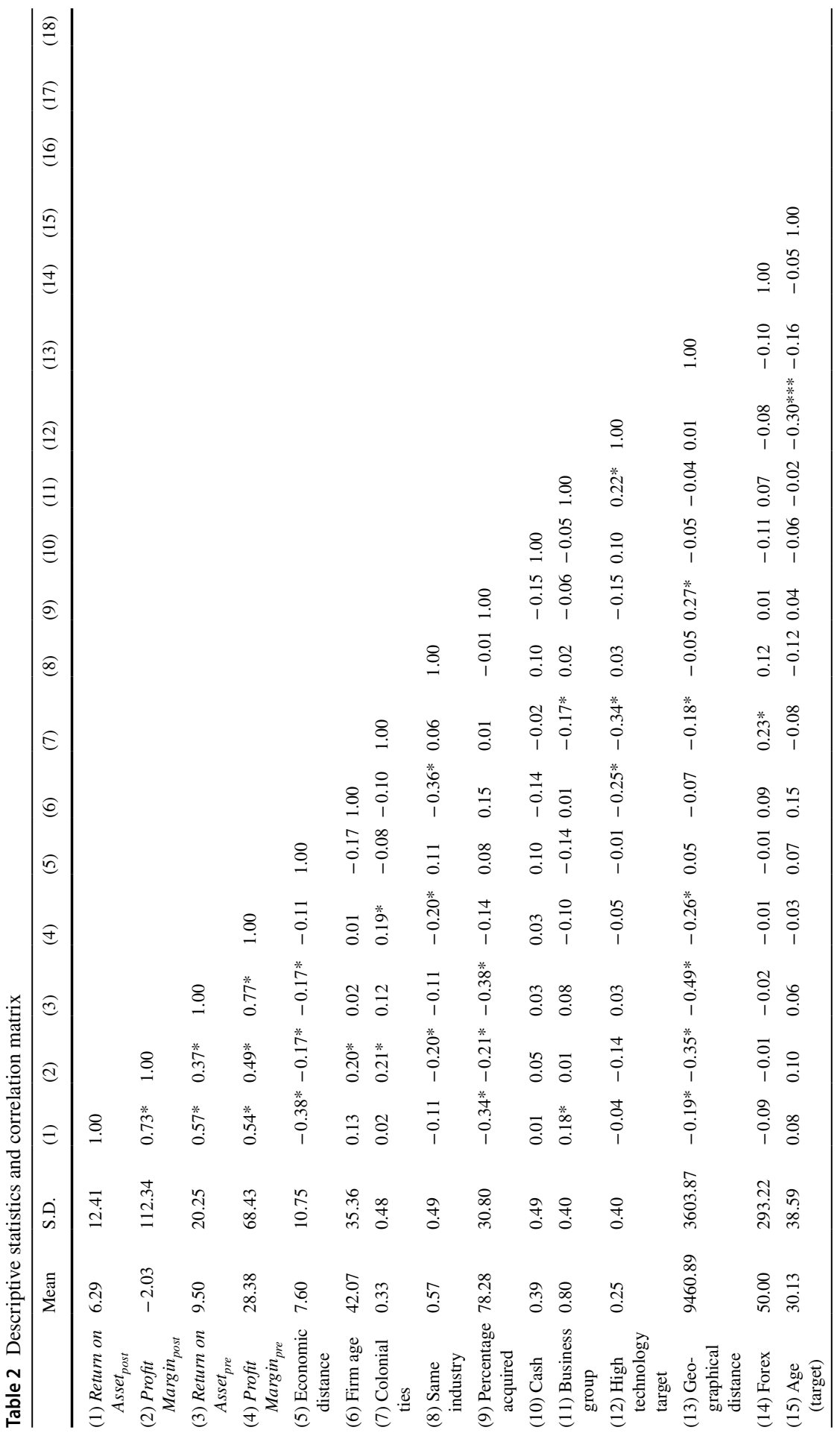




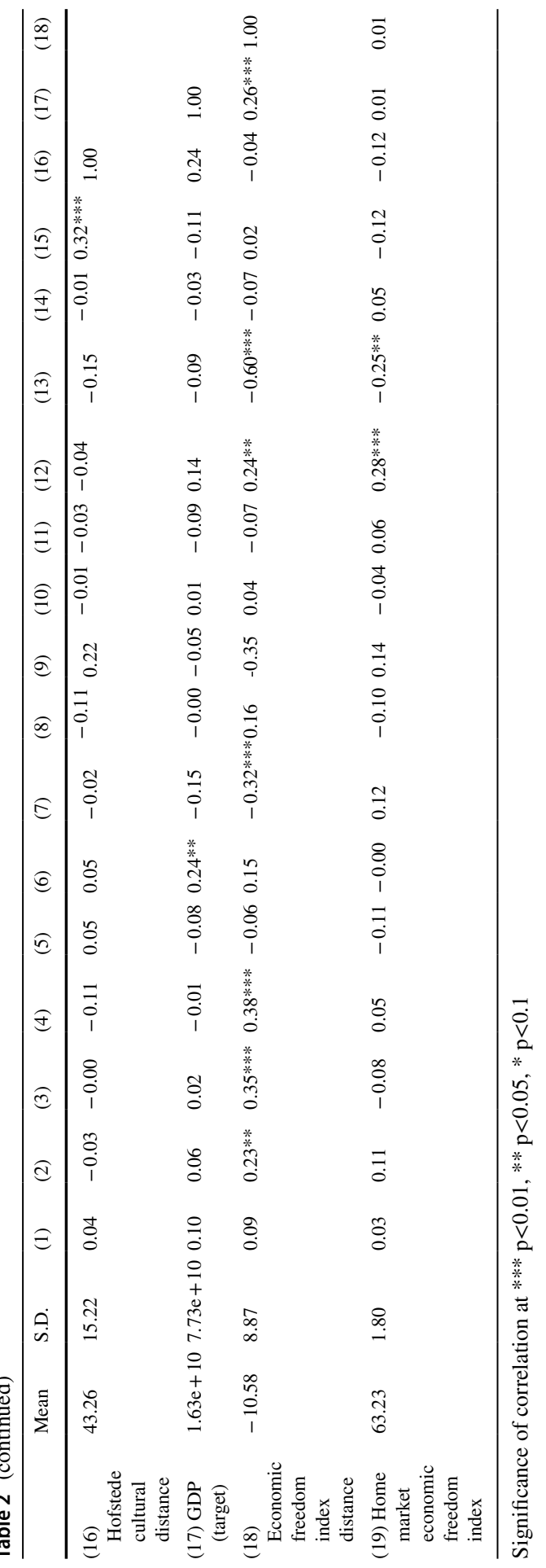


markets (leverage colonial ties, knowledge of colonizers' managerial practices, organizational memory) and firms created after 1994 should invest in developing markets (leverage local knowledge to gain footprint in regional markets).

\subsection{Hypothesis Testing}

In this section, we also explore the effect of the determinants on the post-acquisition performance in a multivariate framework. Tables 4 and 5 present the coefficient estimates from the cross-sectional analysis for the post-acquisition adjusted operating performance in ROA and Profit Margin respectively, with robust standard errors (white estimator) utilized for analyses.

In Tables 4 and 5, we observe a partial support for hypothesis 1 in that younger firms tend to enjoy better post-acquisition performance, though when we consider the full model, we observe that older firms derive better post-acquisition ROA. Specifically, in the Table 4, Model 3 suggests one-year older firm tended to have a decreased ROA by 0.10 unit, while Model 5 suggests one-year older firm experienced an increased ROA by 1.8 unit. In Table 5, Model 4 suggests one-year older firm experienced a decreased Profit Margin by 3.30 unit and Model 5 also suggests one year older firm experienced a reduced Profit Margin of 4.3 unit. Further, we observe that the economic distance decreases EMFs' post-acquisition operating performance in ROA (in Table 4), but not in Profit Margin (in Table 5). We probe the interaction of firm age and economic distance (Model 4, 3 and 5) and find a consistent support for hypothesis 2 in that older firms are better at leveraging the opportunities afforded in the economic distance and improve performance outcomes, as illustrated in the interaction plot in Fig. 1. With one-year increase in age and one unit increase in the economic distance, EMFs increase their ROA by 0.01 and 0.02 unit, respectively. Lastly, we examine the impact of home country institutions interacted with the age of the firm on the performance. We observe that for Profit Margin (in Table 5), in Model 4 and 5, older firms will leverage their experience to overcome home country institutional voids and derive benefits from internalization. Yet, for ROA (in Table 4), though not consistently, we observe that the younger firms can leverage their youth to overcome the institutional voids in their home country. Thus, we have partial support for hypothesis 3, which is further illustrated in Fig. 2.

As for the control variables, as expected, the company's past performance is positively related to the future operating performance for ROA. Extant literature has shown that the business group membership enhances the ability of firms to absorb the synergies from cross-border acquisitions (Guillén 2000; Khanna and Palepu 2000; Yaprak and Karademir 2010). We find that the business group membership has a positive effect on ROA, but a negative effect on Profit Margin, implying that the SA firms are better at deriving the returns from their assets, but do not necessarily have the process or products to derive the monopoly rents.

The targets in the high technology industry are likely to generate a negative ROA and a positive Profit Margin. These results could explain the fact that some of these high-technology targets might indeed provide an opportunity for EMFs 


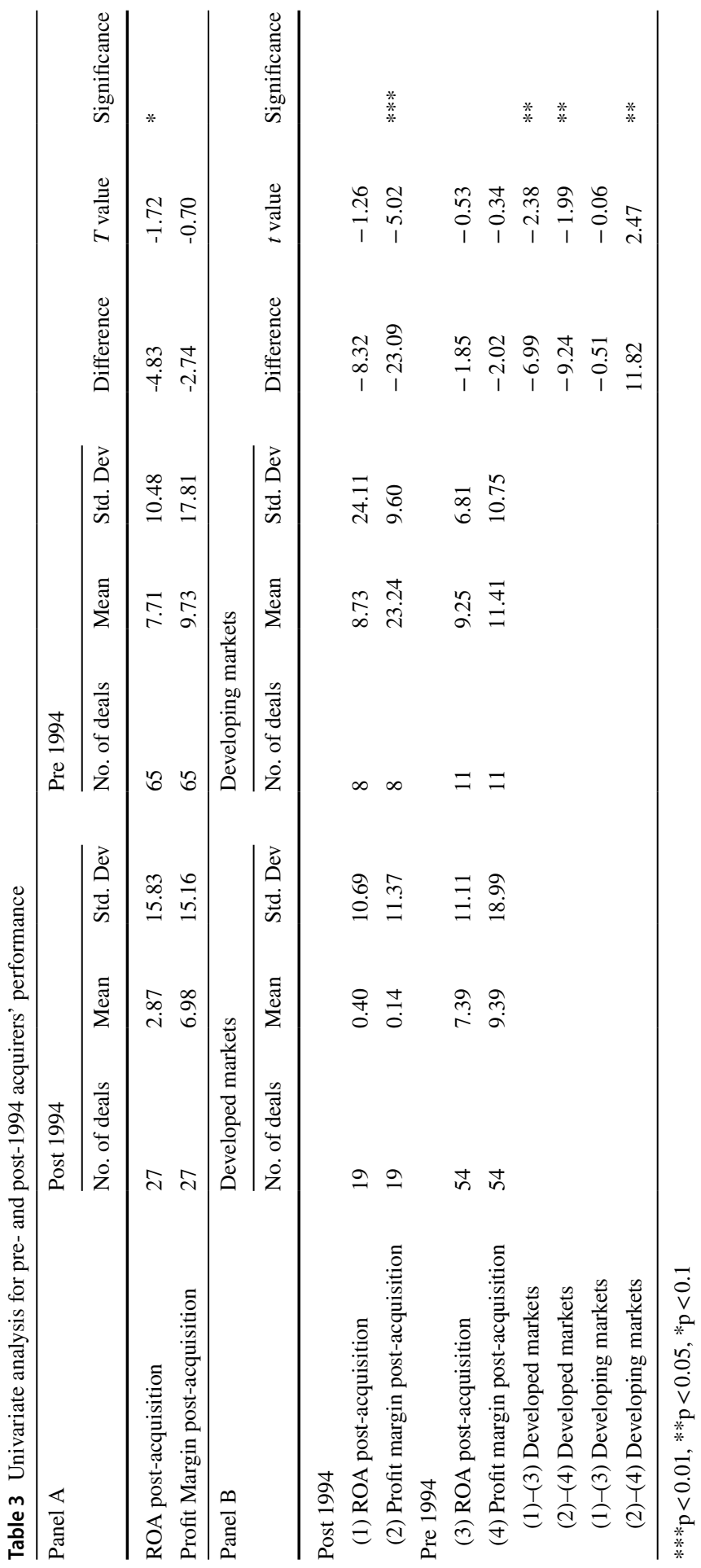


to derive the monopoly rents or superior licensing and protection options. The mode of payment in the form of cash payments for acquisitions is positively and significantly linked to the post-acquisition ROA. It can be argued that cash-rich EMFs derive the value and synergy from their cross-border deals by potentially finding a better use for their slack resources through cross-border acquisitions.

Lagged ROA (Table 4) and Profit Margin (Table 5) have positive impacts on the current performance. The geographic distance is positively related to the postacquisition ROA but is insignificant for the Profit Margin. The currency fluctuations (Forex) have a small, negative affect on ROA. Lastly, the GDP of the host country has a small positive effect on the performance.

\subsection{Robustness Check}

We undertake a series of tests to verify the robustness of our results. On the performance measure, instead of the three-year window for pre- and post-acquisition performance, we decrease this window to one year in the pre- and post-acquisition period. The results stay consistent to those reported. Further, we use another way of calculating the benchmark by adjusting the sample firm's performance to the industry trend (Healy et al. 1992). A separate industry portfolio is created for each acquirer and target firm, which consists of all companies with the same two digits of SIC code. To control for the industry size, the pool of companies is reconstructed every year. The firm with the median value of the operating cash flow return is then selected as the sector median control firm. IAROA is the industry-adjusted return on assets, and IAProfit Margin is the industry-adjusted Profit Margin:

$$
\begin{gathered}
\text { IAProfitMargin }_{i}=\text { ProfitMargin }_{i, t}-\text { medianProfitMargin }_{\text {ind_peer }, t} \\
\text { IAROA }_{i}=R O A_{i, t}-\text { medianROA }_{\text {ind_peer }, t}
\end{gathered}
$$

This benchmark controls for only the industry effect. Hence, the results are less clear (i.e. lower levels of significance) but are largely in the same directions as reported in this research. Also, instead of using the benchmarks described above, we directly use the difference in post-acquisition and pre-acquisition performance as the dependent variables (Ramaswamy 1997; Zollo and Singh 2004). Again, our conclusions remain unchanged.

We also used log value of age and other variables with large standard deviations to control for large variations in values of these variables. The results of these robustness tests are like those presented in this paper. The coefficients of these analysis presented a much stronger effect of our key variables, for example, the coefficient of the firm age in the robustness analysis was 42.21, presenting a much higher magnitude of effect on the firm performance (return on asset).

On the measures of predictors, we use alternate indicators for cultural distance (Hofstede's cultural distance) (Beugelsdijk et al. 2015; Kogut and Singh 1988) and institutional indicators (economic freedom index developed by the Heritage Foundation) in our regression models. The results of these analyses are similar to the results reported. 


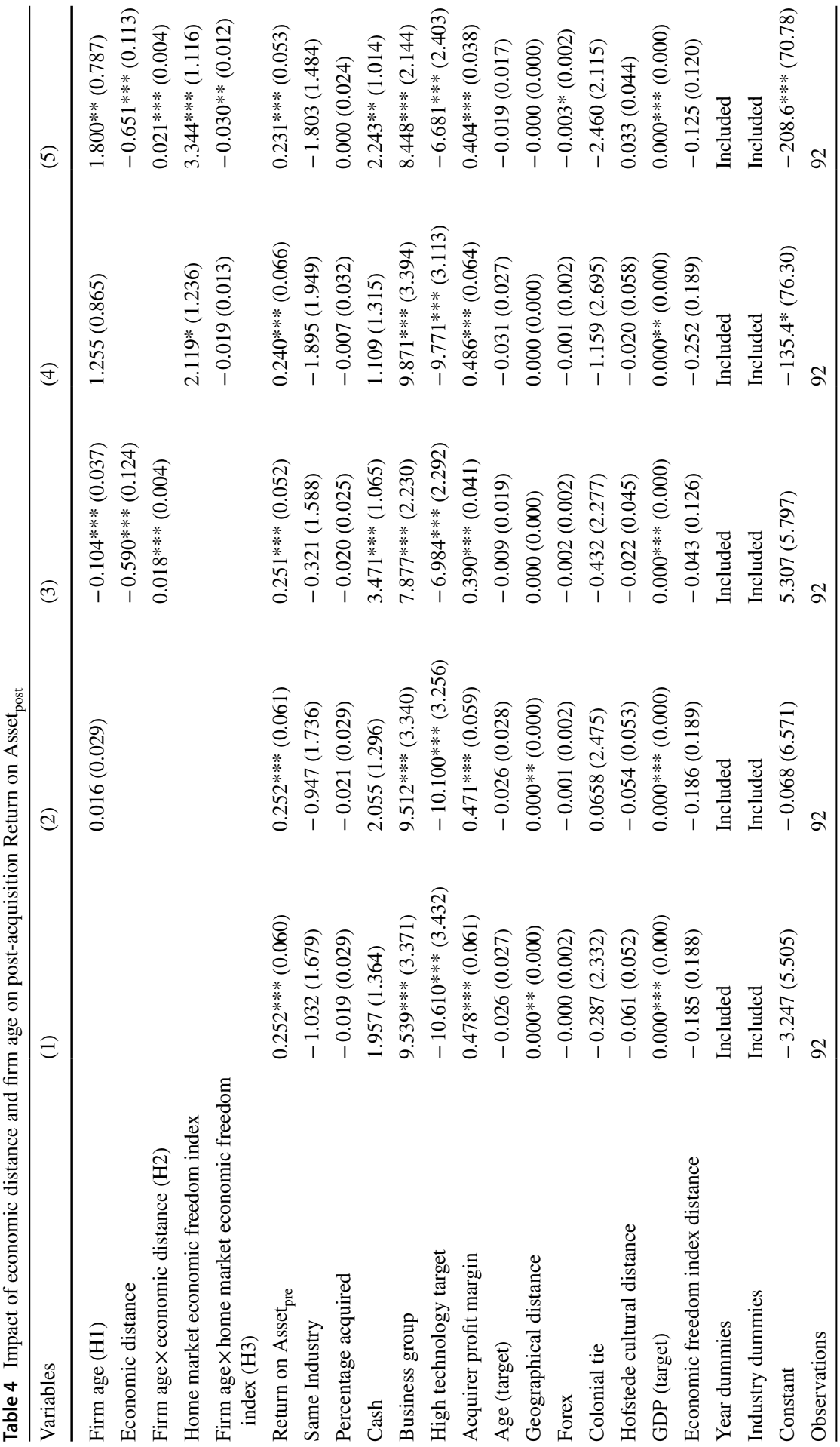




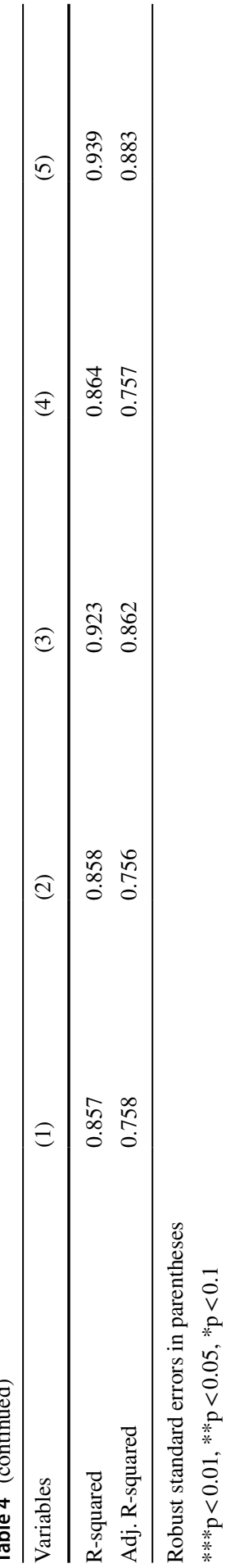

글 Springer 


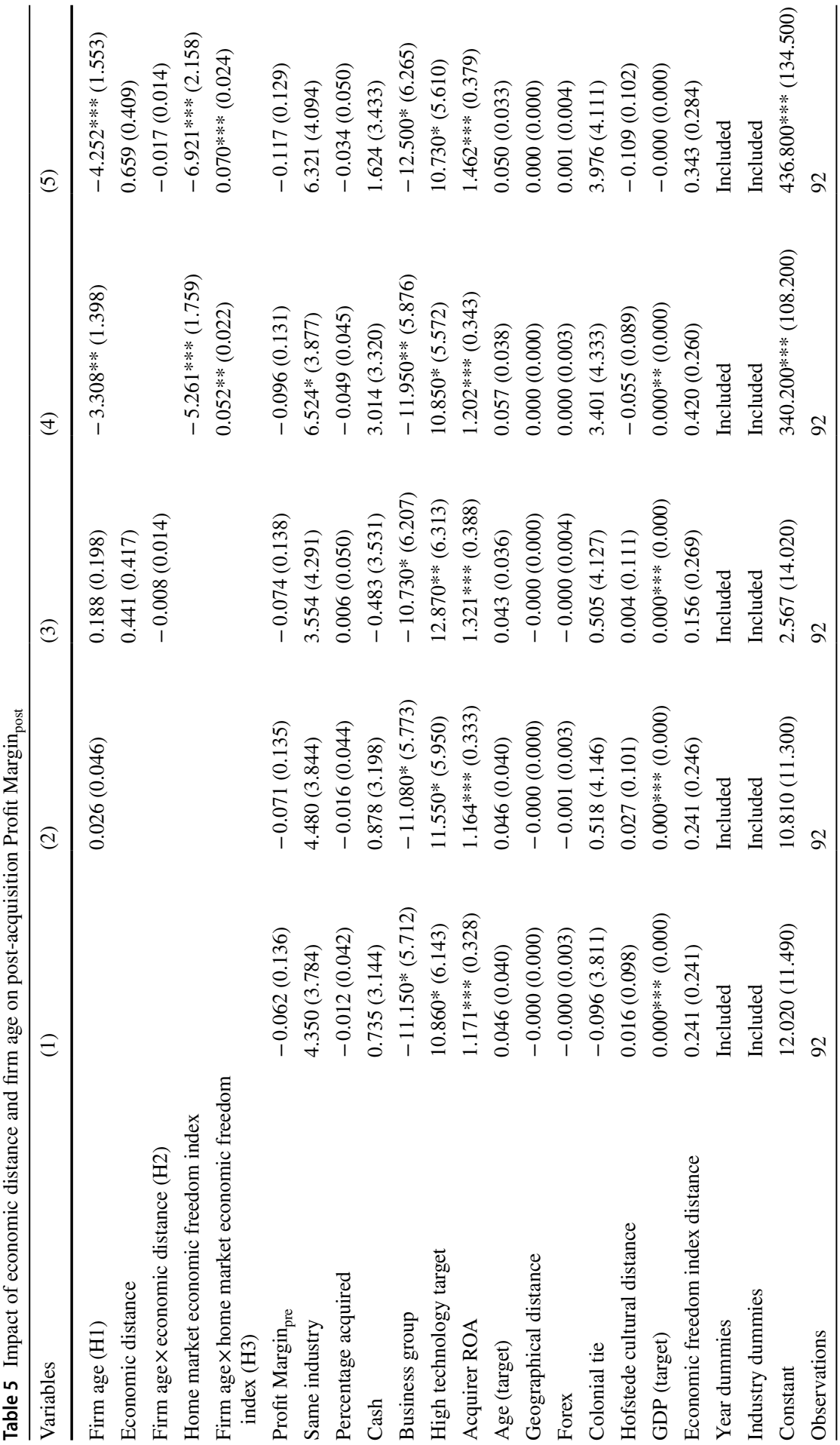




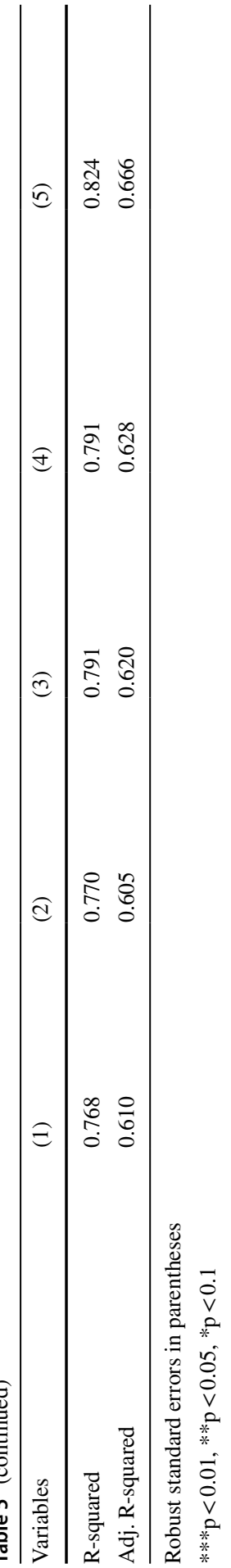




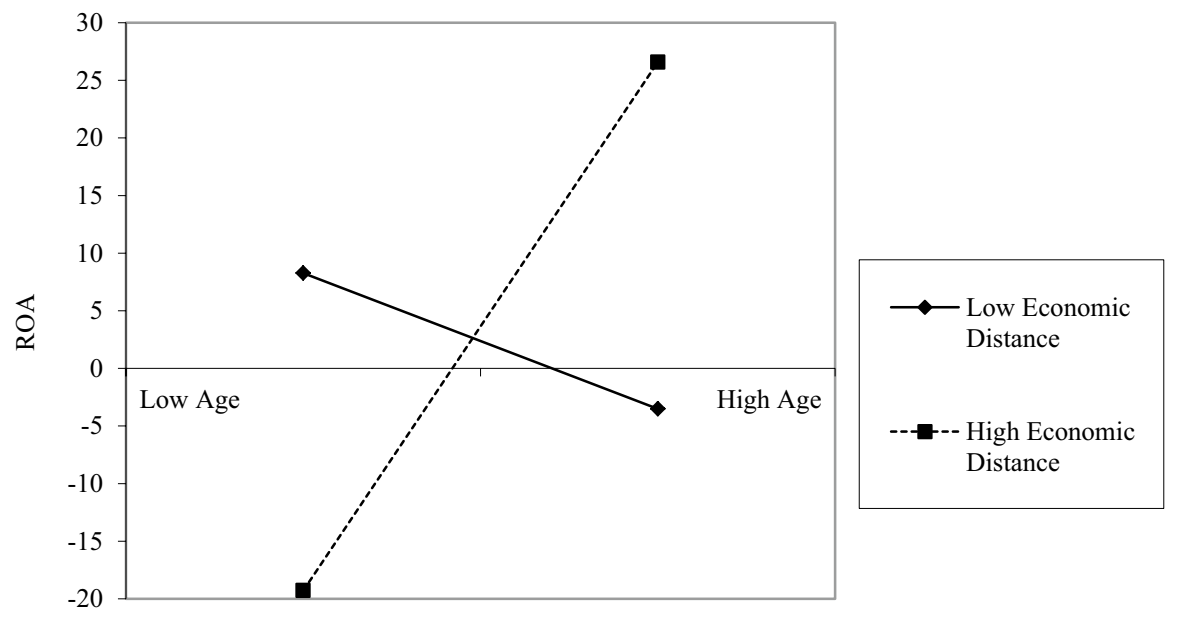

Fig. 1 Two-way interaction of economic distance and firm age on EMF acquirers' post-acquisition ROA

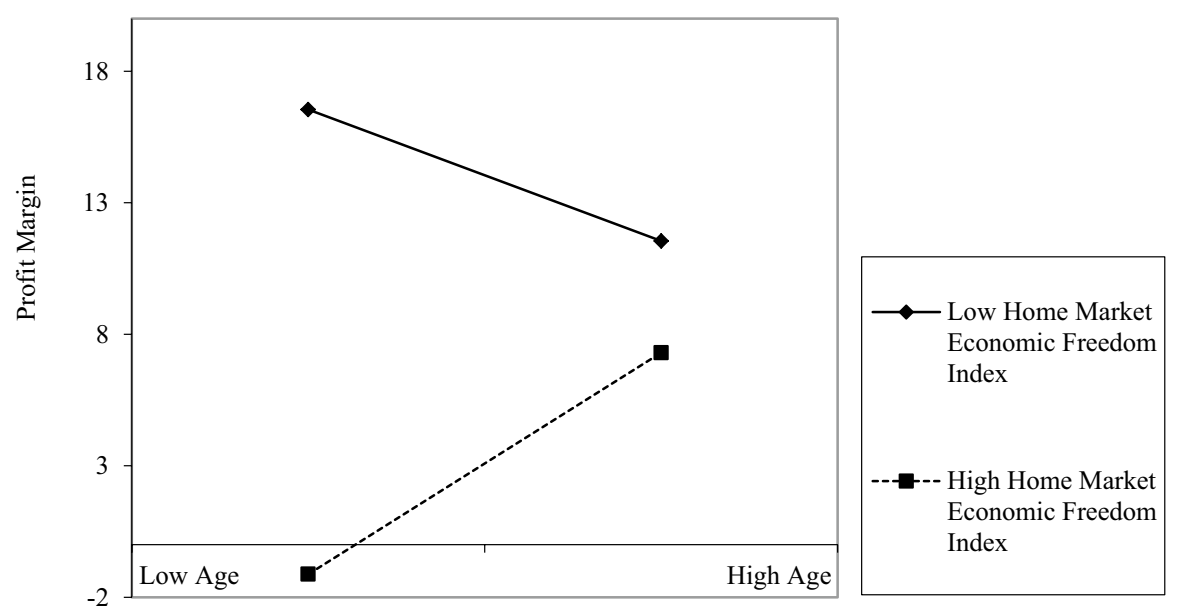

Fig. 2 Two-way interaction of home market economic freedom index and firm age on EMF acquirers' post-acquisition Profit Margin

We also use different control variables in our empirical model. First, instead of only controlling for the business group membership for the acquiring firm, we include an additional dummy variable which indicates the business group membership for the target firms. Second, instead of the same industry classification applied at the 2-digit level, we use a dummy variable to control for the same industry acquisitions at the 4-digit level. Third, we include the number of employees as a proxy to control for the firm size. Due to the missing data on the employment, the sample size is decreased and the effect size is similar. Overall, our conclusions remain unchanged with the additional control variables. 
Next, we introduced the firm size as one of the control variables. As we have several missing values for employee number, the sample size was reduced to 50 . This restricted the use of other controls in the empirical model. Overall, the results obtained in this analysis are similar to those presented in this paper.

\section{Discussion}

While EMFs' cross-border acquisition activities increase, there is still limited research to examine EMF acquirers' post-acquisition operating performance (Ellis et al. 2015). Informed by the springboard perspective and institutional theory, we propose a complex picture of EMFs' post-acquisition operating performance. While we recognize the LLL benefit of early internationalization for EMFs, two country level contingencies provide important boundary conditions. Seemly, EMFs are driven by an entrepreneurial orientation to take the risks of early internationalization and earn a high return on their foreign investment to sustain their growth (Zahra 2005; Zahra and George 2002). Such an entrepreneurial orientation of international new ventures has been documented and seemly contrasted the process model of internationalization (Sapienza et al. 2006). This study evaluates the country level contingencies and bridges these two perspectives. Using a sample of South African firms' acquisitions between 1994 and 2012 in both developed and developing economies, we find the contingency effects of economic distance and economic freedom for EMFs' accelerated internationalization. Despite having a slower growth, older firms tend to benefit more from an economic distance and experience a better postacquisition ROA. With relatively little experience, younger EMFs tend to perform better when acquiring a target in an economically similar country.

Further, we observe that the firm age has different effects on various measures of operating performance. Profit Margin exemplifies how a company's management utilizes investors' money and whether management is growing the company's value at an acceptable rate, while ROA indicates how much profit a company earns for every South African Rand of its assets. For South African firms, the combined effect of economic distance and firm age enhances ROA, but not for Profit Margin. These results indicate the amount of leverage embedded in the established South African acquirers, suggesting an additional mediating mechanism for future research.

Our findings contribute to the literature in multiple ways. First, we add to the discourse on EMFs' competitive advantage and disadvantage. The firm age is a proxy to measure the EMF acquirers' organizational capability established over time (Anand and Delios 2002; Hamel and Prahalad 1993; Sapienza et al. 2006; Stinchcombe 1965). Our results support that EMFs benefit from an accelerated internationalization and enjoy a larger increase in the post-acquisition performance at a young age, but younger EMFs do not perform as well as older firms while acquiring a target in an economically distant country. The ownership advantage through the organizational capabilities established overtime enables the EMFs to further accrue the synergy benefit resided in the economic distance. Hence, even though EMFs benefit from internationalizing at a young age, EMF ought to carefully evaluate the location advantage of internationalization and ideally first internalize into a country 
with a similar market condition before expanding business landscape in a market with larger economic distance, a strategy that is consistent with the classic internationalization model (Johanson and Vahlne 1977, 1990). Thus, this work highlights the necessity of the strategic management of cross-border acquisitions by EMFs and how these newly internationalizing firms can derive the value in cross-border transactions.

Second, in line with a recent call for a more refined understanding of the home country institutional constraint of LLL framework (Lu et al. 2017), our findings support the interaction effect of the country level characteristics, including economic distance and economic freedom, on EMFs' post-acquisition operating performance. While economic distance in general negatively impacts the EMF acquirers' postacquisition performance, the home emerging economy in transition in terms of its economic freedom presents significant challenges. The internalization benefit holds for younger firms who are able to mitigate the lack of economic freedom at home by acquiring a foreign target and improving their Profit Margin.

Third, our study contributes to the discourse of whether we need a new internationalization theory for EMFs (Ramamurti 2016). The EMFs' early internationalization addresses the unique challenges presented in the institutional environment in their home markets. The complex interaction effect between EMF's organizational capability and country level characteristics further reveals and validates the benefit for EMFs to follow a sequential learning process in internationalization. EMFs will enjoy a greater benefit of expanding into a drastically different economic environment after they have accumulated the international experience in a similar foreign market. Therefore, the findings of our research are not in support of a whole new internationalization theory. Instead, we integrate the LLL framework, which provides detailed explanations in EMFs strategic behaviors in upgrading their capabilities (Mathews 2006, 2017), with the springboard perspective of EMFs which highlights the institutional constraints of the internationalization (Luo and Tung 2007, 2018). By doing so, the findings of the current study highlight the importance of the institutional context of emerging economies and enrich our understanding by extending the boundary condition of the process model of internationalization.

\subsection{Limitation and Future Research}

Researchers have recently proposed institutions and organizational resources as two major theoretical building blocks to study the organizational effectiveness in emerging economies (Zoogah et al. 2015). Indeed, not all EMFs can effectively align their organizational resources to absorb the learning opportunities afforded in the diffident institutional environment in the foreign markets. As Sapienza et al. (2006) suggest, an early internationalization propels the young firms' growth and yet, endangers young firms' survival rate due to the intense capability requirement to compete in a foreign market. To evaluate the post-acquisition performance, we only included EMFs that have overcome the challenges of post-acquisition integration and survived at least three years after the acquisition events. We encourage further research to examine EMFs' survival rate and address the potent research question 
as for whether an early internationalization endangers EMFs' chance of surviving in today's global business environment. Further, we do not have data on the prior acquisition of our sample firms as these firms are typically involved in singular acquisitions in our period of analysis. We acknowledge this as one of the limitations of our study. In the current stage of internationalization of the South African firms, most firms are typically involved in fewer acquisitions compared to their western counterparts. Nevertheless, in future, it is likely that these firms will acquire more both domestically as well as in foreign markets. Thus, future studies can capture the experience effects of these SA firms in their studies.

Moreover, in the current study, we use the firm age as a proxy for organizational capability to discuss the LLL benefit of EMF's internationalization (Anand and Delios 2002; Hamel and Prahalad 1993; Sapienza et al. 2006; Stinchcombe 1965). We encourage researchers to further study other types of EMFs' organizational capabilities that are effective in alleviating legitimacy threat presented by institutional distance. For instance, resource fungibility refers to the extent to which resources are deployed for alternative uses at a low cost and maybe able to improve young EMFs' capability to overcome challenges in a drastically different economic environment (Sapienza et al. 2006). Also, the top management team members' international experience and the board diversity may provide significant resources and social capital for EMFs' early internationalization.

The data collection among emerging economy research presents great challenges in conducting firm level research (Klingebiel and Stadler 2015). As this research shows, albeit difficult and time-consuming, it is possible to develop a robust database and rigorous measures to examine the post-acquisition performance of EMF acquirers. Though not sufficiently representative for the entire African continent, this work highlights the difficulty as well as the usefulness of developing a pan-African database to examine the impact of cross-border acquisitions by African firms. We urge other authors to conduct further research in this area by examining other acquisitions from the African continent and other emerging economies.

Open Access This article is distributed under the terms of the Creative Commons Attribution 4.0 International License (http://creativecommons.org/licenses/by/4.0/), which permits unrestricted use, distribution, and reproduction in any medium, provided you give appropriate credit to the original author(s) and the source, provide a link to the Creative Commons license, and indicate if changes were made.

\section{References}

Alon, I., Yeheskel, O., Lerner, M., \& Zhang, W. (2013). Internationalization of Chinese entrepreneurial firms. Thunderbird International Business Review, 55(5), 495-512.

Anand, J., \& Delios, A. (2002). Absolute and relative resources as determinants of international expansion. Strategic Management Journal, 23(2), 119-134.

Ataullah, A., Le, H., \& Sahota, A. S. (2014). Employee productivity, employment growth, and the crossborder acquisitions by emerging market firms. Human Resource Management, 53(6), 987-1004.

Aybar, B., \& Ficici, A. (2009). Cross-border acquisitions and firm value: An analysis of emerging-market multinationals. Journal of International Business Studies, 40(8), 1317-1338.

Aykut, D., \& Goldstein, A. (2007). Developing country multinationals: South-South investment comes of age. In D. O'Connor \& M. Kjollerstrom (Eds.), Industrial Development for the 21st Century: Sustainable Development Perspectives (pp. 85-116). New York: United Nations. 
Barber, B. M., \& Lyon, J. D. (1997). Detecting long-run abnormal stock returns: The empirical power and specification of test statistics. Journal of Financial Economics, 43(3), 341-372.

Barney, J. (1991). Firm resources and sustained competitive advantage. Journal of Management, 17(1), 99-120.

Beccalli, E., \& Frantz, P. (2009). M\&A operations and performance in banking. Journal of Financial Services Research, 36(2-3), 203.

Beltratti, A., \& Paladino, G. (2013). Is M\&A different during a crisis? Evidence from the European banking sector. Journal of Banking \& Finance, 37(12), 5394-5405.

Berry, H., Guillén, M., \& Zhou, N. (2010). An institutional approach to cross-national distance. Journal of International Business Studies, 41(9), 1460-1480.

Bertrand, O., \& Betschinger, M.-A. (2012). Performance of domestic and cross-border acquisitions: Empirical evidence from Russian acquirers. Journal of Comparative Economics, 40(3), 413-437.

Beugelsdijk, S., Maseland, R., \& van Hoorn, A. (2015). Are scores on Hofstede's dimensions of national culture stable over time? A Cohort analysis. Global Strategy Journal, 5(3), 223-240.

Björkman, I., Stahl, G. K., \& Vaara, E. (2007). Cultural differences and capability transfer in cross-border acquisitions: The mediating roles of capability complementarity, absorptive capacity, and social integration. Journal of International Business Studies, 38(4), 658-672.

Chakrabarti, R., Gupta-Mukherjee, S., \& Jayaraman, N. (2009). Mars-Venus marriages: Culture and cross-border M\&A. Journal of International Business Studies, 40(2), 216-236.

Clark, K., \& Ofek, E. (1994). Mergers as a means of restructuring distressed firms: An empirical investigation. Journal of Financial and Quantitative Analysis, 29(4), 541-565.

Criscuolo, P., \& Narula, R. (2007). Using Multi-hub structures for international R\&D: Organisational inertia and the challenges of implementation. Management International Review, 47(5), 639-660.

Cuervo-Cazurra, A. (2012). Extending theory by analyzing developing country multinational companies: Solving the goldilocks debate. Global Strategy Journal, 2(3), 153-167.

Cuervo-Cazurra, A., \& Genc, M. (2011). Obligating, pressuring, and supporting dimensions of the environment and the non-market advantages of developing countries multinational companies. Journal of Management Studies, 48(2), 441-455.

Cuervo-Cazurra, A., \& Ramamurti, R. (2015). The escape motivation of emerging market multinational enterprises. In Perspectives on topical foreign direction investment issues. Columbia FDI Perspectives, p. 143.

Davenport, T. R. H., \& Saunders, C. (2000). South Africa: A modern history (5th ed.). New York: St. Martin's Press.

Denis, D., Denis, D., \& Yost, K. (2002). Global diversification, industrial diversification, and firm value. The Journal of Finance, 57(5), 1951-1979.

Dunning, J. H. (1980). Toward an eclectic theory of international production: Some empirical tests. Journal of international business studies, 11(1), 9-31.

Díaz, K. B. D., Azofra, S. S., \& Gutiérrez, C. L. (2009). Are M\&A premiums too high? Analysis of a quadratic relationship between premiums and returns. Quarterly Journal of Finance and Accounting, 48(3), 5-21.

Dickerson, A. P., Gibson, H. D., \& Tsakalotos, E. (1997). The impact of acquisitions on company performance: Evidence from a large panel of UK firms. Oxford Economic Papers, 49(3), 344-361.

Eden, L., \& Miller, S. R. (2004). Distance matters: Liability of foreignness, institutional distance and ownership strategy. In M. A. Hitt \& J. L. C. Cheng (Eds.), Theories of the multinational enterprise: diversity, complexity and relevance (advance in international management) (Vol. 16, pp. 187-221). Bingley: Emerald Group Publishing Limited.

Elango, B., \& Pattnaik, C. (2007). Building capabilities for international operations through networks: A study of Indian firms. Journal of International Business Studies, 38(4), 541-555.

Ellis, K., Lamont, B., Reus, T., \& Faifman, L. (2015). Mergers and acquisitions in Africa: A review and an emerging research agenda. Africa Journal of Management, 1(2), 137-171.

Ernst \& Young (2012). M\&A in a two-speed world: Assessing risks and opportunities in rapid growth markets.

Estrin, S., Meyer, K. E., \& Pelletier, A. (2018). Emerging economy MNEs: How does home country munificence matter? Journal of World Business, 53(4), 514-528.

Ghemawat, P. (2001). Distance still matters. Harvard Business Review, 79(8), 137-147.

Guillén, M. F. (2000). Business groups in emerging economies: A resource-based view. Academy of Management Journal, 43(3), 362-380. 
Guillén, M. F., \& Garcia-Canal, E. (2009). The American model of the multinational firm and the "new" multinationals from emerging economies. The Academy of Management Perspectives, 23(2), 23-35.

Haleblian, J., \& Finkelstein, S. (1999). The influence of organizational acquisition experience on acquisition performance: A behavioral learning perspective. Administrative Science Quarterly, 44(1), 29-56.

Hamel, G., \& Prahalad, C. K. (1993). Strategy as stretch and leverage. Harvard Business Review, 71(2), 75-84.

Healy, P., Palepu, K., \& Ruback, R. (1992). Does corporate performance improve after mergers? Journal of Financial Economics, 31(2), 135-175.

Heritage Foundation. (2014). Index of economic freedom. Washington: Heritage Foundation.

Hitt, M., Harrison, J., Ireland, R. D., \& Best, A. (1998). Attributes of successful and unsuccessful acquisitions of US firms. British Journal of Management, 9(2), 91-114.

Ismail, A. I., Rose, R. C., Abdullah, H., \& Uli, J. (2010). The relationship between organizational competitive advantage and performance moderated by the age and size of firms. Asian Academy of Management Journal, 15(2), 157-173.

Johanson, J., \& Vahlne, J. (1977). The internationalization process of the firm-A model of knowledge development and increasing foreign market commitments. Journal of International Business Studies, 8(1), 23-32.

Johanson, J., \& Vahlne, J. (1990). The mechanism of internationalization. International Market Review, 7(4), 11-24.

Jones, M. V. (1999). The internationalization of small high-technology firms. Journal of International marketing, 7(4), 15-41.

Khanna, T., \& Palepu, K. (2000). The future of business groups in emerging markets: Long-run evidence from Chile. Academy of Management Journal, 43(3), 268-285.

Klingebiel, R., \& Stadler, C. (2015). Opportunities and challenges for empirical strategy research in Africa. Africa Journal of Management, 1(2), 194-200.

Kogut, B., \& Singh, H. (1988). The effect of national culture on the choice of entry mode. Journal of International Business Studies, 19(3), 411-432.

Kolstad, I., \& Wiig, A. (2011). Better the devil you know? Chinese foreign direct investment in Africa. Journal of African Business, 12(1), 31-50.

Kostova, T., \& Zaheer, S. (1999). Organizational legitimacy under conditions of complexity: The case of the multinational enterprise. Academy of Management Review, 24(1), 64-81.

Li, J., Li, Y., \& Shapiro, D. (2012). Knowledge Seeking and Outward FDI of Emerging Market Firms: The Moderating Effect of Inward FDI. Global Strategy Journal, 2(4), 277-295.

Li, J., Li, P., \& Wang, B. (2016). Do cross-border acquisitions create value? Evidence from overseas acquisitions by Chinese firms. International Business Review, 25(2): 471-483.

Linn, S. C., \& Switzer, J. A. (2001). Are cash acquisitions associated with better postcombination operating performance than stock acquisitions? Journal of Banking \& Finance, 25(6), 1113-1138.

Liou, R., Chao, M. C. H., \& Ellstrand, A. (2017). Unpacking institutional distance: Addressing human capital development and emerging-market firms' ownership strategy in an advanced economy. Thunderbird International Business Review, 59(3), 281-295.

Liou, R., \& Nicholson, R. (2017). Out of Africa: The role of institutional distance and host-home colonial tie in South African firms' post-acquisition performance in developed economies. International Business Review, 26(6), 1184-1195.

Liou, R., Rao-Nicholson, R., \& Sarpong, D. (2018). What is in a name? Cross-national distances and subsidiary's corporate visual identity change in emerging-market firms' cross-border acquisitions. International Marketing Review, 35(2), 301-319.

Lu, J., Ma, X., Taksa, L., \& Wang, Y. (2017). From LLL to IOL: Moving dragon multinationals research forward. Asia Pacific Journal of Management, 34(4), 757-768.

Luo, Y., \& Tung, R. L. (2007). International expansion of emerging market enterprises: A springboard perspective. Journal of International Business Studies, 38(4), 481-498.

Luo, Y., \& Tung, R. L. (2018). A general theory of springboard MNEs. Journal of International Business Studies, 49(2), 129-152.

Makino, S., Lau, C., \& Yeh, R. (2002). Asset-exploitation versus asset-seeking: Implications for location choice of foreign direct investment from newly industrialized economies. Journal of International Business Studies, 33(3), 403-421. 
Makri, M., Hitt, M. A., \& Lane, P. J. (2010). Complementary technologies, knowledge relatedness, and invention outcomes in high technology mergers and acquisitions. Strategic Management Journal, 31(6), 602-628.

Martin, K. J. (1996). The method of payment in corporate acquisitions, investment opportunities, and management ownership. The Journal of Finance, 51(4), 1227-1246.

Martynova, M., Oosting, S., \& Renneboog, L. (2007). The long-term operating performance of European mergers and acquisitions. In G. Gregoriou \& L. Renneboog (Eds.), International mergers and acquisitions activity since 1990: Recent research and quantitative analysis (pp. 79-116). Massachusetts: Elsevier.

Mathews, J. A. (2002). Competitive advantages of the latecomer firm: A resource-based account of industrial catch-up strategies. Asia Pacific journal of management, 19(4), 467-488

Mathews, J. A. (2006). Dragon multinationals: New players in 21st century globalization. Asia Pacific Journal of Management, 23(1), 5-27.

Mathews, J. A. (2017). Dragon multinationals powered by linkage, leverage and learning: A review and development. Asia Pacific Journal of Management, 34(4), 769-775.

Meyer, K. E., Estrin, S., Bhaumik, S. K., \& Peng, M. W. (2009). Institutions, resources, and entry strategies in emerging economies. Strategic Management Journal, 30(1), 61-80.

Moeller, S. B., \& Schlingemann, F. P. (2005). Global diversification and bidder gains: A comparison between cross-border and domestic acquisitions. Journal of Banking \& Finance, 29(3), 533-564.

Moeller, S. B., Schlingemann, F. P., \& Stulz, R. M. (2004). Firm size and the gains from acquisitions. Journal of Financial Economics, 73(2), 201-228.

Nicholson, R. R., \& Salaber, J. (2013). The motives and performance of cross-border acquirers from emerging economies: Comparison between Chinese and Indian firms. International Business Review, 22(6), 963-980.

O’Driscoll, G. P., Jr., Feulner, E. J., \& O'Grady, M. A. (2003). Index of economic freedom. Washington: Heritage Foundation.

Papadakis, V. M., \& Thanos, I. C. (2010). Measuring the performance of acquisitions: An empirical investigation using multiple criteria. British Journal of Management, 21(4), 859-873.

Peng, M. W. (2003). Institutional transitions and strategic choices. Academy of Management Review, 28(2), 275-296.

Peng, M. W., Wang, D., \& Jiang, Y. (2008). An institution-based view of international business strategy: A focus on emerging economies. Journal of International Business Studies, 39(5), 920-936.

Peteraf, M. A., \& Barney, J. B. (2003). Unraveling the resource based tangle. Managerial and Decision Economics, 24(4), 309-323.

Popli, M., \& Sinha, A. K. (2014). Determinants of early movers in cross-border merger and acquisition wave in an emerging market: A study of Indian firms. Asia Pacific Journal of Management, 31(4), 1075-1099.

Porter, M. (1990) The competitive advantage of nations. Harvard Business Review, 68(2), 73-93.

Puranam, P., \& Srikanth, K. (2007). What they know vs. what they do: How acquirers leverage technology acquisitions. Strategic Management Journal, 28(8), 805-825.

Ramamurti, R. (2012). What is really different about emerging market multinationals? Global Strategy Journal, 2(1), 41-47.

Ramamurti, R. (2016). Internationalization and innovation in emerging markets. Strategic Management Journal, 37(13), E74-E83.

Ramaswamy, K. (1997). The performance impact of strategic similarity in horizontal mergers: evidence from the US banking industry. Academy of Management Journal, 40(3), 697-715.

Rao-Nicholson, R., \& Cai, C. (2018). The effects of ownership identity on corporate diversification strategy of Chinese companies in foreign markets. Asia Pacific Journal of Management, 1, 1. https:// doi.org/10.1007/s10490-018-9578-8.

Rao-Nicholson, R., \& Khan, Z. (2017). Standardization versus adaptation of global marketing strategies in emerging market cross-border acquisitions. International Marketing Review, 34(1), 138-158.

Rao-Nicholson, R., Salaber, J., \& Cao, T. H. (2016). Long-term performance of mergers and acquisitions in ASEAN countries. Research in International Business and Finance, 36, 373-387.

Reus, T. H., \& Lamont, B. T. (2009). The double-edged sword of cultural distance in international acquisitions. Journal of International Business Studies, 40(8), 1298-1316. 
Rossi, S., \& Volpin, P. F. (2004). Cross-country determinants of mergers and acquisitions. Journal of Financial Economics, 74(2), 277-304.

Sapienza, H. J., Autio, E., George, G., \& Zahra, S. A. (2006). A capabilities perspective on the effects of early internationalization on firm survival and growth. Academy of Management Review, 31(4), 914-933.

Schoenberg, R. (2006). Measuring the performance of corporate acquisitions: An empirical comparison of alternative metrics. British Journal of Management, 17(4), 361-370.

Schreyögg, G., \& Kliesch-Eberl, M. (2007). How dynamic can organizational capabilities be? Towards a dual-process model of capability dynamization. Strategic Management Journal, 28(9), 913-933.

Shleifer, A., \& Vishny, R. W. (2003). Stock market driven acquisitions. Journal of Financial Economics, 70(3), 295-311.

Stahl, G. K., \& Tung, R. L. (2015). Towards a more balanced treatment of culture in international business studies: The need for positive cross-cultural scholarship. Journal of International Business Studies, 46(4), 391-414.

Stinchcombe, A. L. (1965). Social structure and organizations. In J. G. March (Ed.), Handbook of organizations (pp. 142-193). Chicago: Rand McNally.

Sudarsanam, S. (2003). Creating value from mergers and acquisitions: the challenges: an integrated and international perspective. Harlow: Pearson Education.

Tan, B. R., \& Chintakananda, A. (2016). The effects of home country political and legal institutions on firms' geographic diversification performance. Global Strategy Journal, 6(2), 105-123.

Thanos, I. C., \& Papadakis, V. M. (2012a). Unbundling acquisition performance: How do they perform and how can this be measured? In D. Faulkner, et al. (Eds.), Handbook of mergers and acquisitions. Oxford: Oxford University Press.

Thanos, I. C., \& Papadakis, V. M. (2012b). The use of accounting-based measures for measuring M\&A performance: A review of five decades of research. In C. L. Cooper \& S. Finkelstein (Eds.), Advances in mergers and acquisitions (Vol. 10, pp. 103-120). Bingley: Emerald Group Publishing Limited.

Tian, X. (2017). Learning breakdown in latecomer multinational enterprises. Asia Pacific Journal of Management, 34(4), 823-850.

Tsang, E. W., \& Yip, P. S. (2007). Economic distance and the survival of foreign direct investments. Academy of Management Journal, 50(5), 1156-1168.

UNCTAD (United Nations Conference on Trade and Development). (2015). World investment report, 2015. New York: United Nations.

Weimer, M., \& Vines, A. (2011). UK-South Africa relations and the bilateral forum. London: Chatham House.

Wilson, D., \& Purushothaman, R. (2003). Dreaming with BRICs: The path to 2050 (p. 99). New York: Goldman, Sachs \& Company.

Wright, M., Filatotchev, I., Hoskisson, R. E., \& Peng, M. W. (2005). Strategy research in emerging economies: Challenging the conventional wisdom. Journal of Management Studies, 42(1), 1-33.

Xu, D., Pan, Y., \& Beamish, P. W. (2004). The effect of regulative and normative distances on MNE ownership and expatriate strategies. Management International Review, 44(3), 285-307.

Yaprak, A., \& Karademir, B. (2010). The internationalization of emerging market business groups: An integrated literature review. International Marketing Review, 27(2), 245-262.

Zahra, S. (2005). A theory of international new ventures: A decade of research. Journal of International Business Studies, 36(1), 20-28.

Zahra, S., \& George, G. (2002). International entrepreneurship: The current status of the field and future research agenda. In M. Hitt, et al. (Eds.), Strategic entrepreneurship: creating an integrated mindset (pp. 255-288). Oxford: Blackwell.

Zollo, M., \& Meier, D. (2008). What is M\&A performance? The Academy of Management Perspectives, 22(3), 55-77.

Zollo, M., \& Singh, H. (2004). Deliberate learning in corporate acquisitions: post-acquisition strategies and integration capability in US bank mergers. Strategic Management Journal, 25(13), 1233-1256.

Zoogah, D. B., Peng, M. W., \& Woldu, H. (2015). Institutions, resources, and organizational effectiveness in Africa. The Academy of Management Perspectives, 29(1), 7-31.

Publisher's Note Springer Nature remains neutral with regard to jurisdictional claims in published maps and institutional affiliations. 